\title{
STUDY THE EFFECTIVENESS OF OUTRIGGER STRUCTURAL SYSTEM DURING PROGRESSIVE COLLAPSE OF HIGH RISE CONCRETE BUILDING
}

\author{
Pragnesh C. Patel ${ }^{1}$, Digesh D. Joshi², Paresh V. Patel ${ }^{3}$ \\ ${ }^{1}$ Civil Engineering Department, Institute of Technology, Nirma University, Ahmedabad 382481, Gujarat, India \\ ${ }^{2}$ Civil Engineering Department, Institute of Technology, Nirma University, Ahmedabad 382481, Gujarat, India \\ ${ }^{3}$ Civil Engineering Department, Institute of Technology, Nirma University, Ahmedabad 382481, Gujarat, India
}

\begin{abstract}
One of the major causes for failures of many high profile structures took place, around the world, is extreme loading effects generated due to hurricane, flood, earthquake, explosion and terrorist attacks on buildings. This type of event imposes abnormal loading on the building structure. Generally, members of building are not designed to resist this type of abnormal loading and results into failure. One of the mechanisms of failure during such event is referred to as "Progressive Collapse". In the current study, progressive collapse potential of 50-storey RC building with outrigger structural system is evaluated. Outriggers are basically rigid horizontal structural members connected between external columns and central core. Effectiveness of different locations of outriggers throughout the height of building on progressive collapse resistance is studied under two different column removal scenarios. Non-linear static analysis is performed for removal of corner column and side face column, separately, from bottom storey, by following U. S. General Service Administration (GSA) guidelines. Modelling, analysis and design of building is carried out using MIDAS Gen software. From the analysis results, it is observed that building with outriggers provided at mid height location and at top exhibits superior progressive collapse resistance.
\end{abstract}

Keywords: Progressive Collapse, Outrigger Structural System, Non-linear Static Analysis, High Rise Building, Column Removal Scenario

\section{INTRODUCTION}

High rise buildings are rapidly increasing in major cities around the world, due to advances in construction techniques, scarcity of urban land, rise in land value, evolution of structural systems and enhancement of computational capabilities. For any high rise building, it is important to provide innovative and efficient structural system for high rise buildings, which controls drift and acceleration of building, in order to satisfy serviceability constraints as well as human comfort levels. The outrigger and belt truss system consists central core connected with the perimeter column which gives column free space between core and exterior columns. It is one of the lateral load resisting system in which the external column are tied with RC or braced steel frame main core with stiff horizontal cantilever members at one or more levels commonly referred as outriggers. In addition to those columns located at the ends of the outrigger, it is also mobilize other peripheral columns to assists in restraining outriggers. This achieved by including deep spandrel girder or truss called belt truss. Few examples of buildings with outrigger structural system are Victoria Office Tower in Montreal, Wisconsin Centre in Milwoukee, Taipai 101 Tower etc.

Structural engineers are facing challenges in designing of structures due to increase in terrorist attacks which causes damage and harm to the safety of the people. Conventionally, the buildings are designed for gravity and lateral loads but any abnormal loads are generally not considered in design. As a result structure undergoes failure, when subjected to abnormal loading. One of the mechanism of failure during such abnormal loading is known as "Progressive Collapse".

Progressive collapse is a situation where local failure of a primary structural component leads to the collapse of adjoining members, which in turn leads to spread of collapse. Progressive collapse is defined as "the spread of an initial local failure from element to element resulting in the collapse of an entire structure or a disproportionately large part of it" [1]. It is a chain reaction failure of building members to an extent disproportionate to the original localized damage [2]. Progressive collapse of building structures is initiated when one or more vertical load carrying members are seriously damaged or collapsed during any of the abnormal events. Once a local failure takes place, the building's gravity load transfers to neighboring members in the structure. If these members are not properly designed to resist and redistribute the additional load, that part of the structure also fails. As a result, a substantial part of the structure may collapse, causing greater damage to the structure than the initial impact. Thus it is necessary to provide sufficient redundancy, ductility and continuity, 
which helps the structure to find alternate paths for load distribution during undesired failure event and thus to reduce progressive collapse.

The design of progressive collapse resistant building structures is not a new problem in the field of structural Engineering. Many structural Engineers and academic researchers have been engaged in the prevention of progressive collapse since the partial collapse of Ronan Point apartment building in 1968. After the bombing of the Murrah Federal Building in 1995 and collapse of Khobar Tower in 1996, several considerable changes have been made in the design philosophy of the important building. But after the collapse of World Trade Center Towers in September 2001, interest of structural engineers is increased in evaluating the progressive collapse potential for the buildings. Among these guidelines, the U. S. General Service Administration (GSA) [1] and Unified Facilities Criteria (UFC 4-023-03) published by Department of Defense (DoD) [2] provides detailed step wise procedure and methodologies to resist the progressive collapse of building structures. One of the method recommended by these guidelines is Alternate Load Path method, which emphasize on redundancy of the building so that it can be able to resist the additional redistributed forces without collapse during loss of primary load resisting elements.

Marjanishvili and Agnew [3] studied different methods for progressive collapse analysis of 9-storey moment resisting steel frame. Mashhadiali and Kheyroddin [4] investigated the progressive collapse resisting capacities of 28-storey and 48-storey buildings with tube-type diagrid and the newly developed hexa-grid structural systems, subjected to sudden removal of the structural elements in the first story. Ren et al. [5] evaluated the progressive collapse resistance of two 15-storey RC frame shear wall structures under various column / shear wall removal scenarios. Kim and Lee [6] performed progressive collapse analysis of different types of diagrid structures, with and without corner columns, and tubular structure with closely spaced external columns and deep spandrel girders. Kim and Park [7] studied progressive collapse potential of 36-storey building structures with RC core walls and outrigger trusses as a major lateral loadresisting system in which two types of perimeter frames were designed i.e. with mega-columns $\&$ with belt trusses at top storey. Kim et al. [8] assessed the robustness of moment resisting steel frame considering different bays and different number of storey by performing pushdown analysis.

The main objective of this paper is to evaluate progressive collapse potential of 50-storey $\mathrm{RC}$ building with outrigger structural system under two separate column removal condition from bottom storey. Effect of different locations of outriggers provided along the height of the building i.e. (i) at top (ii) at mid height (iii) at $1 / 3^{\text {rd }}$ height and (iv) at $2 / 3^{\text {rd }}$ height is investigated. Non-linear static analysis is performed by following U. S. General Service Administration (GSA) guidelines. Modelling, analysis and design of building is carried out using MIDAS Gen software [9].

\section{BUILDING CONFIGURATION}

In this study, 50-storey residential RC building is considered [10] which is designed as per IS 456:2000 [11]. It is having three bays of $8 \mathrm{~m}$ each in both $\mathrm{x}$-direction and $\mathrm{z}$-direction with overall plan size equals to $24 \mathrm{~m} \times 24$ $\mathrm{m}$. Typical storey height is considered as $3.5 \mathrm{~m}$. The overall height of the building is $175 \mathrm{~m}$. Typical floor plan and elevation of the building considered for the study is shown in Fig-1.

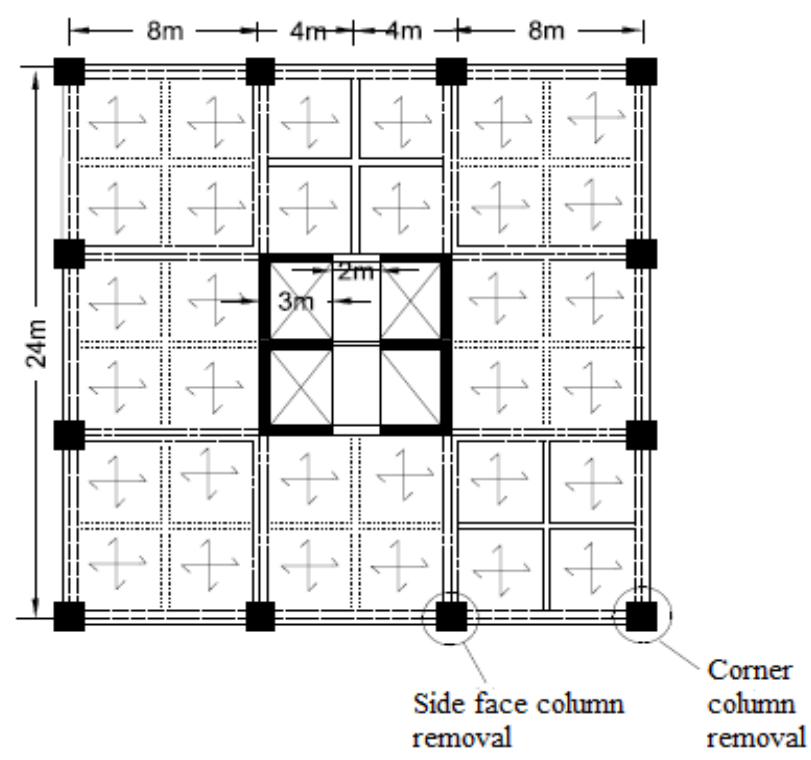

Fig-1: Plan of Building

Shear wall of thickness $500 \mathrm{~mm}$ is considered around the core. Slab thickness considered as $125 \mathrm{~mm}$. Beam size for primary beams and secondary beams is taken as $600 \times 950$ $\mathrm{mm}$ and $300 \times 500 \mathrm{~mm}$, respectively. Column size for 50 stroey RC building is considered as $1200 \times 1200 \mathrm{~mm}$. Size of outrigger and belt truss is considered as $500 \times 7000 \mathrm{~mm}$. Fig.-2 shows typical configuration of outriggers provided at different locations through the height and elevation of building. Loading parameters considered on building are as follows:

\section{Gravity Loading Parameters}

Dead load: Self weight of the structural elements Live load: $3 \mathrm{kN} / \mathrm{m} 2$ on floors and $1.5 \mathrm{kN} / \mathrm{m} 2$ on roof Floor finish: $1 \mathrm{kN} / \mathrm{m} 2$

\section{Seismic Loading Parameters [12]:}

Zone III, Soil type - medium soil, Importance factor 1

\section{Wind Loading Parameters [13]:}

Basic wind speed $39 \mathrm{~m} / \mathrm{s}$, terrain category II, building class B

\section{Material Property:}

Grade of concrete $f_{c k}$ : M50

Grade of steel $\mathrm{f}_{\mathrm{y}}$ : Fe 415 


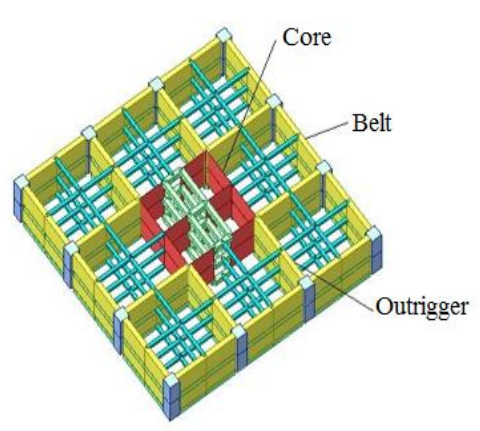

(a)

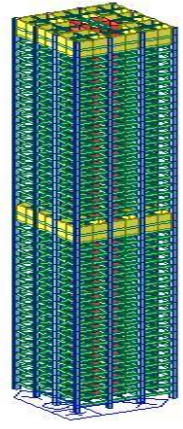

(b)
Fig-2: (a) Configuration of Outrigger (b) Elevation of Building

\section{NONLINEAR STATIC ANALYSIS}

In this study, nonlinear static analysis is performed to investigate the performance of outrigger structural system during column removal scenario. According to GSA guidelines, load combination 2(DL+0.25LL) applied to the adjacent bay of removed column as shown in Fig-3 during nonlinear static analysis method. To consider the dynamic effects, dynamic amplification factor 2 is considered as suggested by guidelines. A nonlinear static analysis method implies a stepwise increase of amplified vertical loads at the location of removed column, until maximum amplified loads are attained or until the structure collapses. This method is also called vertical pushover analysis or pushdown analysis. This method is either load controlled or displacement controlled. This procedure helps in determining elastic and failure limits of the structure. In this paper, results obtained through displacement control nonlinear static pushdown analysis by following GSA guidelines are presented.

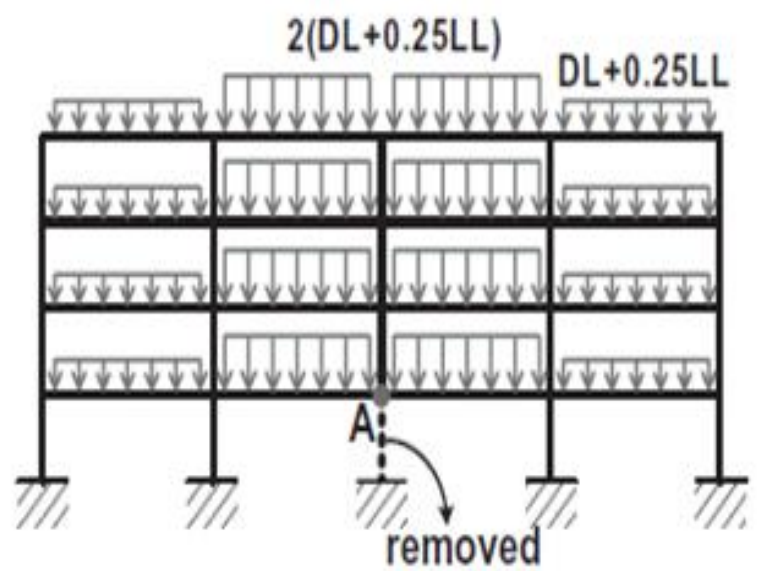

Fig-3: Imposed Gravity Load in Nonlinear Static Analysis

For nonlinear static analysis of flexural members the skeleton curve provided in the FEMA-356 (2000) [14] as shown in Fig-4 is used. It shows the deformation corresponding to Immediate Occupancy (IO) Life Safety (LS), Collapse Prevention (CP) according to FEMA-356. Here $\mathrm{a}, \mathrm{b}$ and $\mathrm{c}$ depends on width-thickness ratio of the member and determined as per FEMA-356 guidelines.

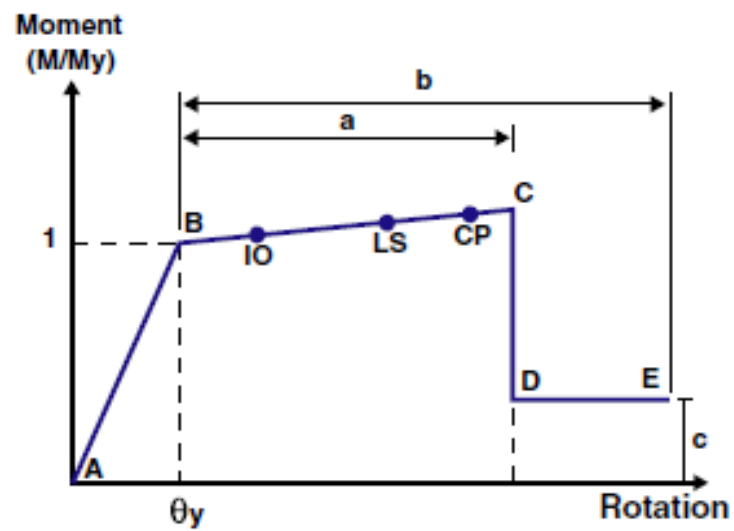

Fig-4: Moment Rotation Relationship for Different Structural Members

The step-wise procedure to perform nonlinear static analysis using MIDAS Gen software is discussed below:

Step-1: Build a computer model of building and perform analysis and design.

Step-2: Impose load as 2(DL+0.25LL) to the bays adjacent to removed column and DL+0.25LL to other bays, as discussed earlier.

Step-3: Define initial global control parameters for nonlinear static analysis as shown in Fig-5.

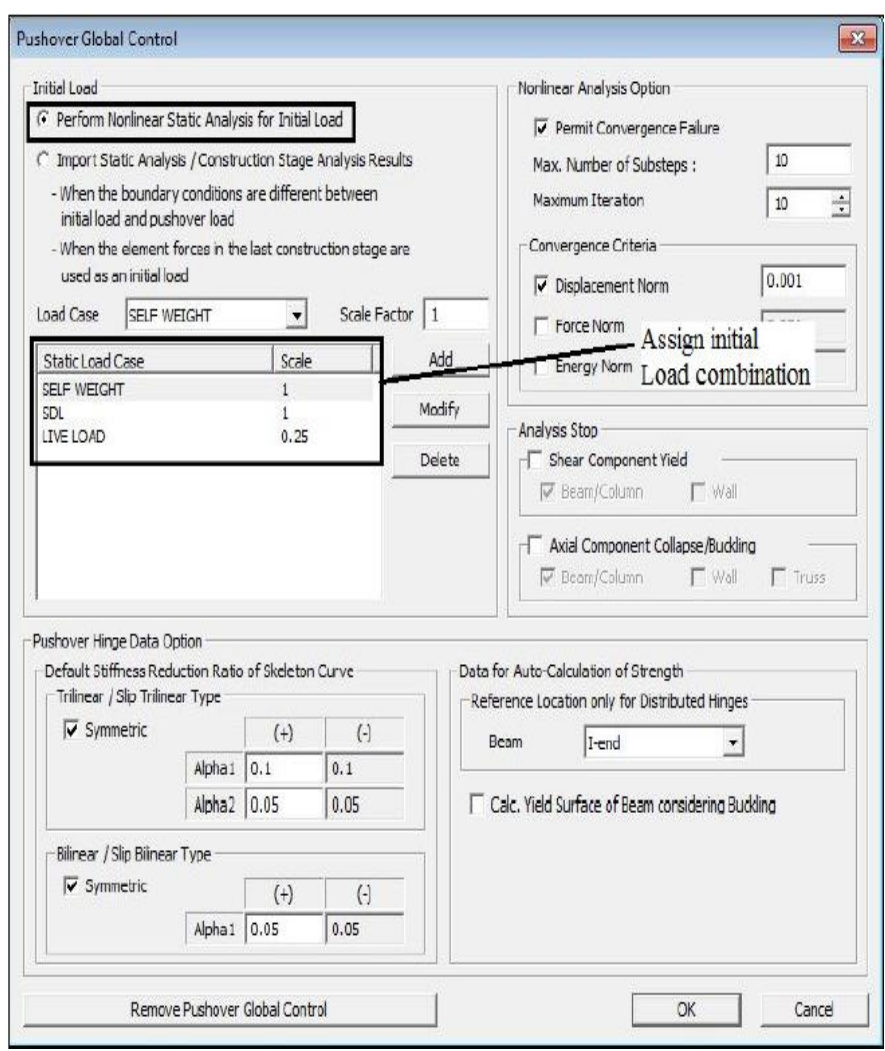

Fig-5: Pushover Global Control Parameter

Step-4: Define load combination as 2(DL+0.25LL) for nonlinear static analysis as shown in Fig-6. 


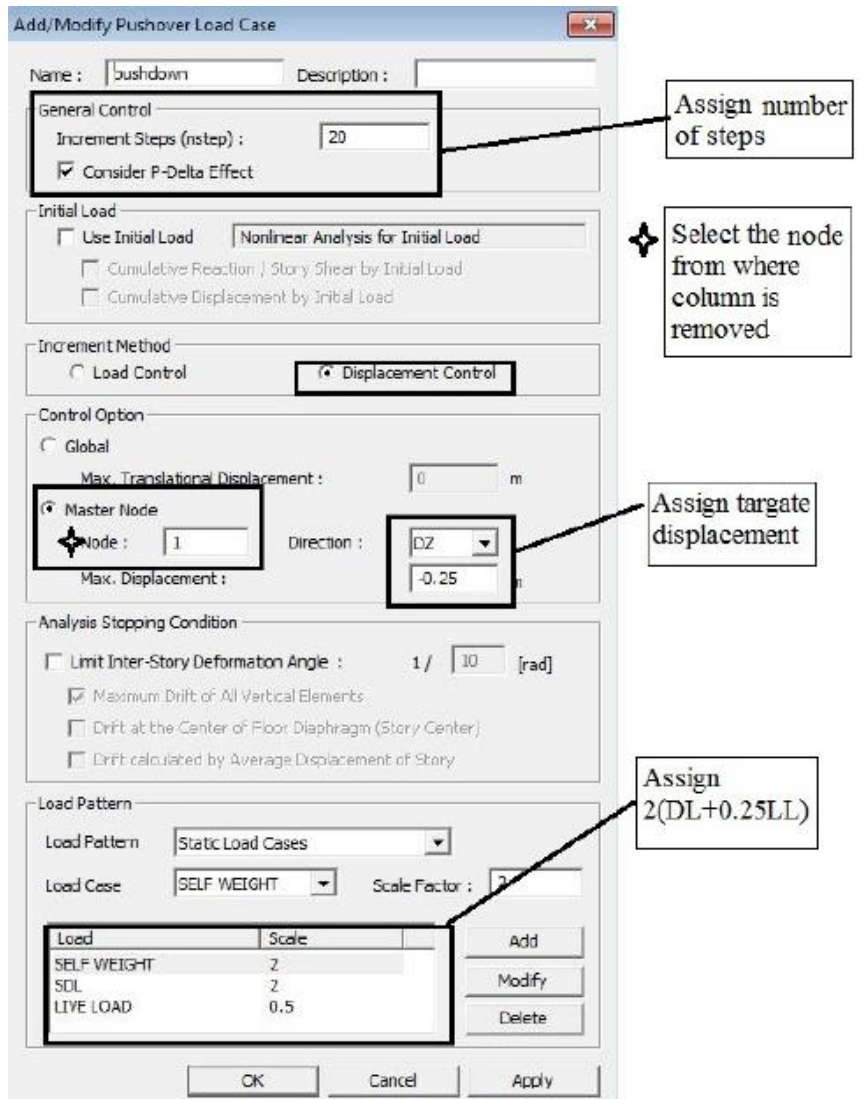

Fig-6: Pushover Load Case Definition

Step-5: Define and assign pushover hinge properties. Automatic plastic hinge properties, as given in MIDAS Gen are assigned. Default M3 hinges are assigned to beams and P-M2-M3 hinges are assigned to columns as well as shear walls at both the ends of the members by releasing $\mathrm{M}_{\mathrm{y}}$ and $\mathrm{F}_{\mathrm{z}}$ component. The snapshots of assignment of hinge properties for beam, column and shear wall are shown in Fig-7.

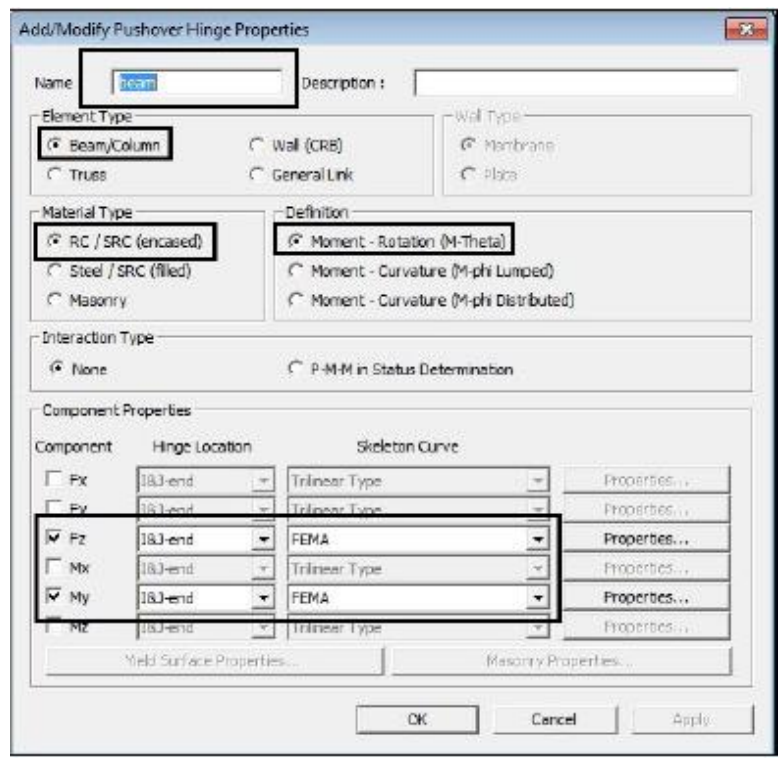

(a)

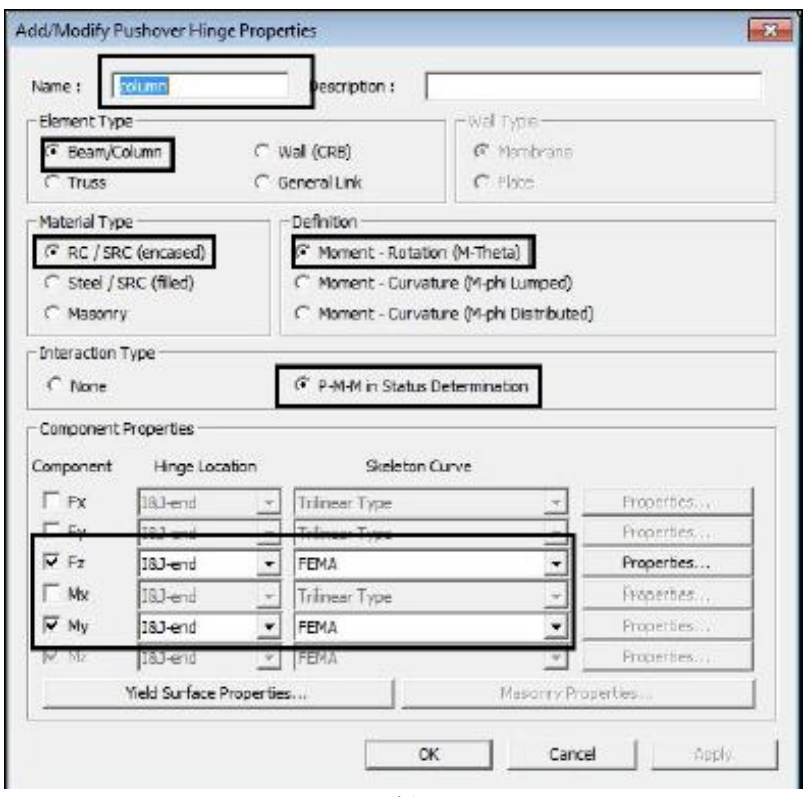

(b)

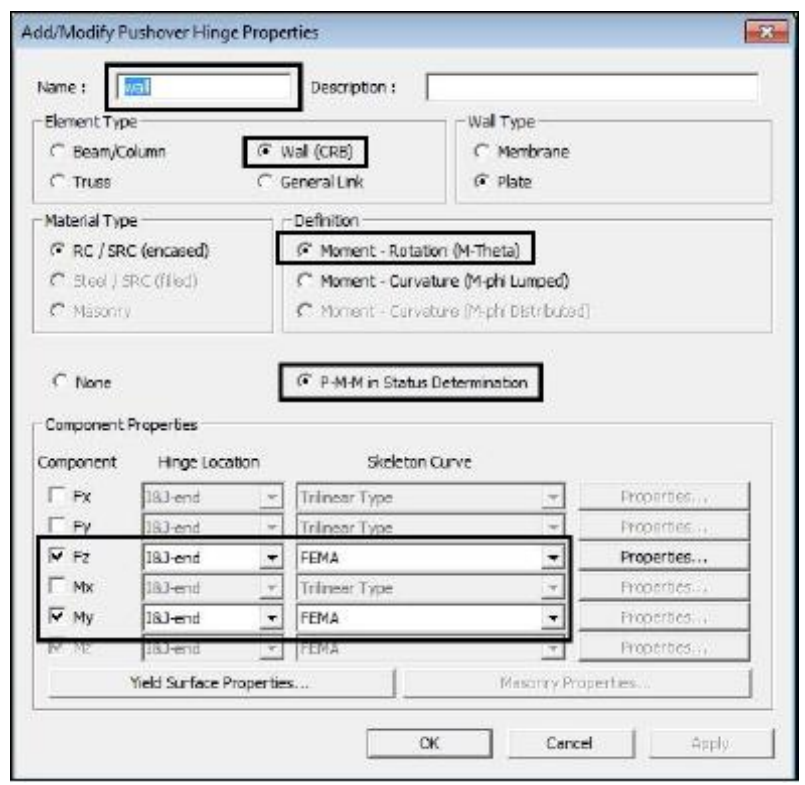

(c)

Fig-7: Hinge Properties for (a) beam (b) column and (c) shear wall

Step-6: Perform the analysis and obtain the results. The output graph of load factor v/s displacement obtained through MIDAS Gen is shown in Fig-8. The results of hinge formation at different steps of analysis can be obtained by selecting appropriate control parameters as shown in Fig-9. 


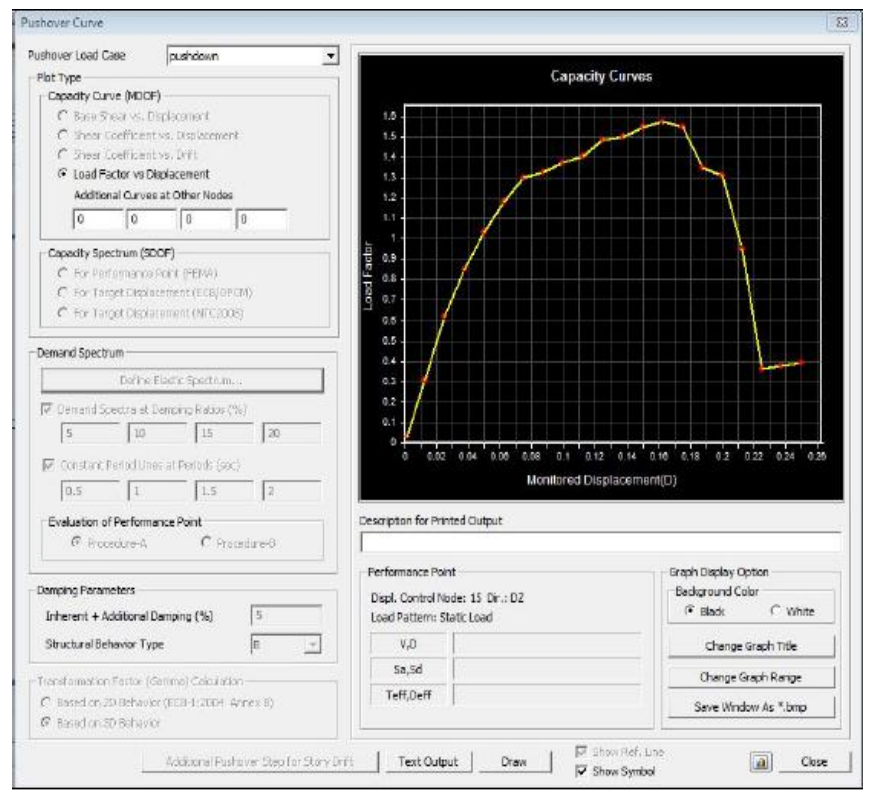

Fig-8: Load factor v/s displacement curve

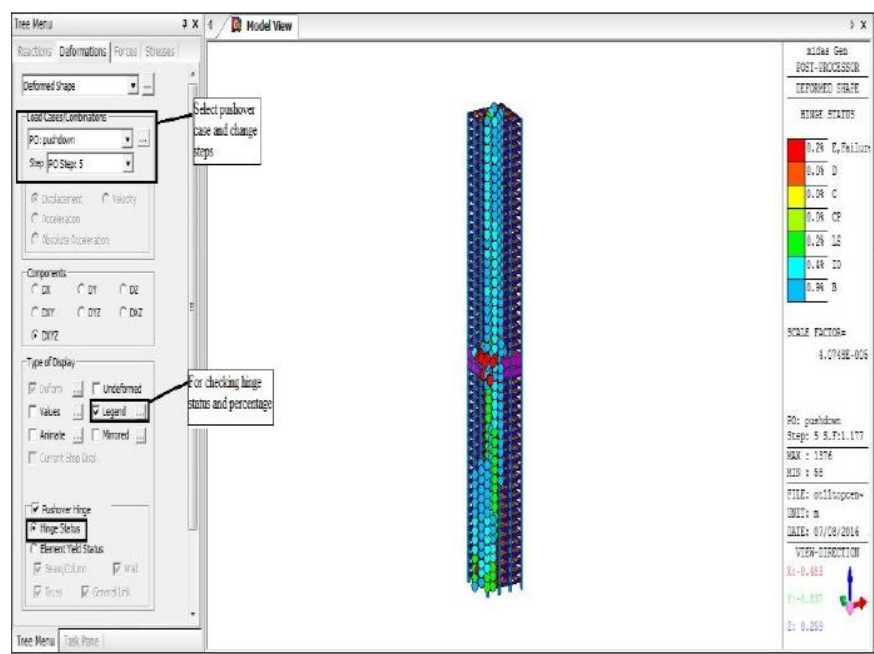

Fig-9: Parameters to obtain results of hinge formation

\section{RESULTS AND DISCUSSION}

The nonlinear static analysis is performed by providing outriggers at different locations along the height of building as shown in Fig-10, following GSA guidelines. Modeling, analysis and design is carried out using MIDAS Gen software. Load Factor is calculated at critical locations under two different column removal scenarios as shown in Fig-1. Load Factor indicates the robustness of structures against progressive collapse and it is calculated as follows:

$$
\text { Load factor }=\frac{\text { Equivalentloadin each step }}{\text { Total Load }}
$$

The comparison of load factor calculated for different locations of outriggers under corner column removal condition is presented in Fig-11. From the analysis results, it is observed that load factor is maximum, when outriggers are provided at mid height as compared to other cases. Higher value of load factor indicates higher resistance offered by building structure against progressive collapse.
The building structure with outriggers provided at mid height also undergoes maximum displacement as compared to other cases.

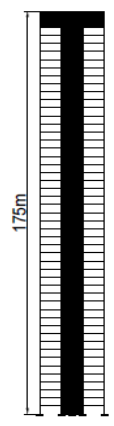

(a)

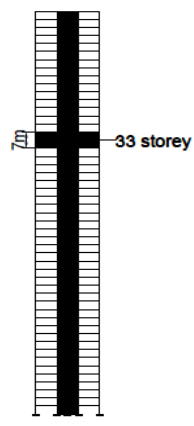

(b)

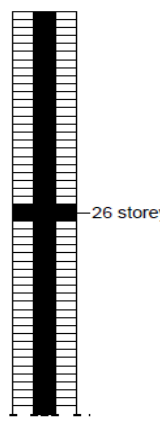

(c)

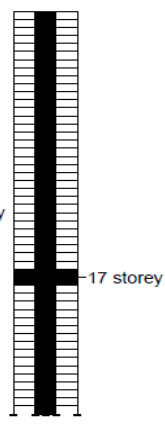

(d)
Fig-10: Location of outrigger along the height of building i.e. (a) at top (b) at $2 / 3^{\text {rd }}$ height (c) at mid height (d) at $1 / 3^{\text {rd }}$ height

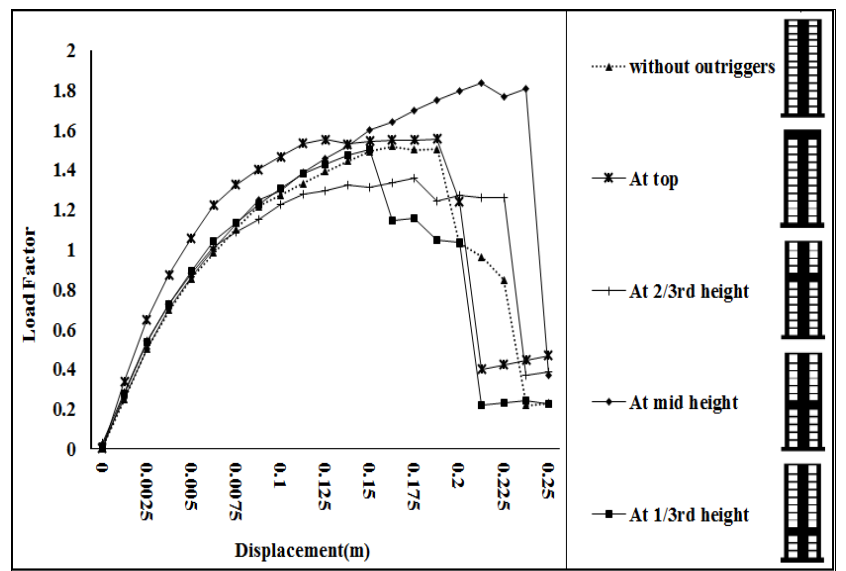

Fig-11: Load Factor for Corner Column Removal

The comparison of load factor during removal of side face column is shown in Fig-12. From the results, it is observed that load factor is very much closer to each other for majority of cases, however it is maximum, when outriggers are provided at $1 / 3^{\text {rd }}$ height, which indicates maximum progressive collapse resistance offered by the building structure. The building structure with outriggers provided at mid height also undergoes maximum displacement as compared to other cases.

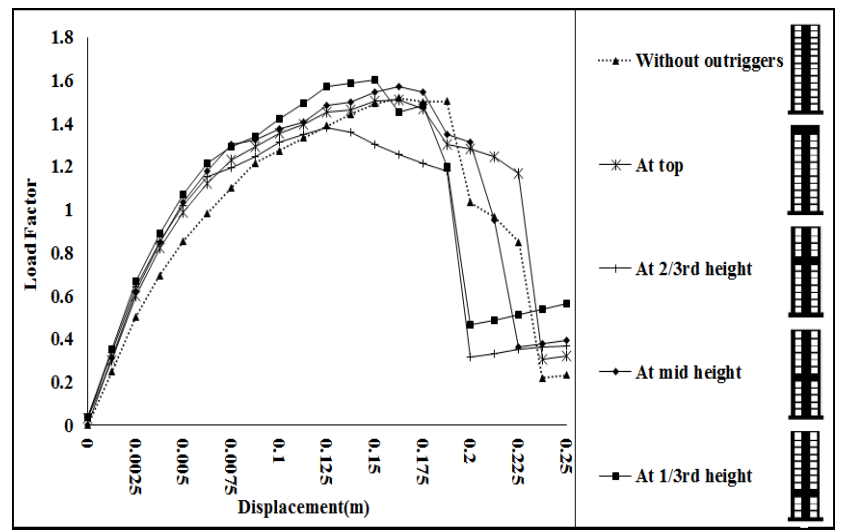

Fig-12: Load factor for Side Face Column Removal 
Value of load factor indicates the load resisting capacity of building. The building structure will undergoes collapse and considered as failed for value of load factor less than 1 . From the comparison of load factor for different location of outriggers under both the column removal scenario as shown in Fig-13, marginal difference is observed in load resistance capacity. It is also evident that, all the cases considered for the study are capable to withstand progressive collapse under both the column removal cases, however outriggers provided at mid height $\&$ at $1 / 3^{\text {rd }}$ height provides better performance compared to other cases during removal of corner column and removal of side face column, respectively.

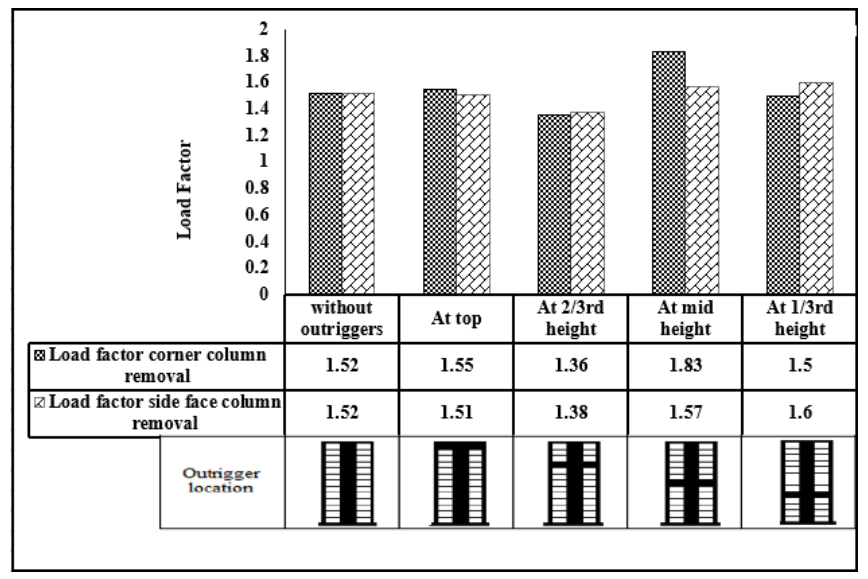

Fig-13: Comparison of Load Factor

Hinge formation in different phases, during the last step of nonlinear static analysis is also studied for all cases. Table-1 and Table- 2 shows percentage of hinge formation in building for different location of outriggers during corner column removal and side face column removal, respectively. Higher percentage of hinge formation indicates better performance as more number of members are participating in collapse resistance. From the Table-1, it is observed that, hinge formation is maximum when outriggers are provided at mid height of the building, during corner column removal, with failure at higher displacement which advocates better performance of building structure as compared to other cases. Similarly, from Table-2, it is seen that hinge formation is maximum when outrigger is provided at the top during removal of side face column.

Table-1: Percentage of Hinge Formation for Corner Column Removal

\begin{tabular}{|l|l|l|l|l|l|}
\cline { 2 - 6 } \multicolumn{1}{c|}{} & \multicolumn{6}{|c|}{ Corner Column Removal } \\
\cline { 2 - 6 } \multicolumn{1}{c|}{} & $\begin{array}{l}\text { Without } \\
\text { outriggers }\end{array}$ & $\begin{array}{l}\text { At top } \\
\text { height }\end{array}$ & $\begin{array}{l}\text { At 2/3 } \\
\text { height }\end{array}$ & $\begin{array}{l}\text { At mid } \\
\text { height }\end{array}$ & $\begin{array}{l}\text { At 1/3 } \\
\text { height }\end{array}$ \\
\hline B & 1.3 & 1.6 & 1.1 & 3.5 & 1.5 \\
\hline IO & 0.3 & 0.3 & 0.7 & 0.9 & 0.4 \\
\hline LS & 0.2 & 0.2 & 0.1 & 0.5 & 0.3 \\
\hline CP & 0 & 0 & 0 & 0 & 0 \\
\hline C & 0 & 0 & 0 & 0 & 0 \\
\hline D & 0 & 0.1 & 0 & 0.1 & 0 \\
\hline E & 18.5 & 2.8 & 3.7 & 21.2 & 4.2 \\
\hline Total & 20.3 & 5 & 5.6 & 26.2 & 6.4 \\
\hline
\end{tabular}

Table-2: Percentage of Hinge Formation for Side Face Column Removal

\begin{tabular}{|c|c|c|c|c|c|}
\hline & \multicolumn{5}{|c|}{ Side Face Column Removal } \\
\hline & $\begin{array}{l}\text { Without } \\
\text { outriggers }\end{array}$ & $\begin{array}{l}\text { At top } \\
\text { height }\end{array}$ & $\begin{array}{l}\text { At } 2 / 3^{\text {rd }} \\
\text { height }\end{array}$ & $\begin{array}{l}\text { At mid } \\
\text { height }\end{array}$ & $\begin{array}{l}\text { At } 1 / 3^{\text {rd }} \\
\text { height }\end{array}$ \\
\hline B & 0.6 & 0.7 & 1.6 & 1.6 & 1 \\
\hline IO & 0.2 & 0.2 & 0.4 & 1.5 & 0.4 \\
\hline $\mathbf{L S}$ & 0.2 & 0.2 & 0.3 & 1.2 & 0.5 \\
\hline $\mathbf{C P}$ & 0 & 0 & 0 & 0.1 & 0 \\
\hline $\mathbf{C}$ & 0 & 0 & 0 & 0 & 0 \\
\hline D & 0 & 0 & 0 & 0.1 & 0 \\
\hline $\mathbf{E}$ & 18.6 & 18.8 & 5.6 & 11.8 & 7.2 \\
\hline Total & 19.6 & 19.9 & 7.9 & 16.3 & 9.1 \\
\hline
\end{tabular}

\section{CONCLUSION}

In this study, nonlinear static analysis of 50-storey $\mathrm{RC}$ building with outrigger structural system is carried out. Effect of different locations of outrigger on progressive collapse resistance during column removal scenario is evaluated. From the analysis results, it is observed that building structure with outrigger provided at mid height location and at $1 / 3^{\text {rd }}$ height is having maximum load factor, for removal of corner column and removal of side face column, respectively. However, marginal difference is observed in load factor for all the cases during removal of side face column. It is also evident that load factor for all the cases is more than 1 , which will not cause progressive failure of building considered for the study during removal of one column at a time. However, present work can be further extended to study the effect of number of column removal simultaneously from different locations on building performance.

\section{REFERENCES}

[1]. GSA, "Progressive collapse analysis and design guidelines for new federal office buildings and major modernization projects", The U.S. General Service Administration: Washington DC; 2003.

[2]. DoD, "Design of Buildings to Resist Progressive Collapse", Unified facilities Criteria- Department of Defence : Washington DC; 2005.

[3]. E. Marjanishvili, E. Agnew. "Comparison of Various Methods for Progressive Collapse Analysis. Journal of performance of Constructed Facilities", Nov.2006; Vol.20: pp 365-374.

[4]. N. Mashhadiali, A. Kheyroddin, "Progressive Collapse Assesment of New hexagrid Structural Syastem for Tall Buildings", Struct. Des. Tall Spec. Build. Aust.2014; Vol.23: pp.947-961.

[5]. P. Ren, Y. Li, H. Guan. "Progresssive Collapse Resistance of Two Typical High-Rise RC Frame Shear Wall Structures", Journal of Performance Constructed Facilities. Jun 2015; Vol: 2.

[6]. J. Kim, Y. Lee, "Progressive Collapse Resistant Capacity of Tube-Type Structures", Struct. Des.Tall Spec. Build. Aust.2010; Vol.19: pp.761-777.

[7]. J. Kim, J. Park. "Progresssive Collapse Resistant Capacity of Building Structures with Outrigger Trusses", 
Struct. Des. Tall Spec. Build. Aust.2012; Vol.21: pp.566577.

[8]. T. Kim, J. Kim, J. Park. "Progressive Collapse Resistant capacity of Steel Moment Resisting Building using Pushdown Analysis", Journal of Perfomance Constructed facilities. Oct.2009; Vol.23; pp 327-335.

[9]. MIDAS GenW.2012.General Structure Design System for Windows, MIDAS Information Technology Co Ltd: Seoul, Korea.

[10]. Patel JC. "Study of Outrigger Structural System for High Rise Buildings" (M. Tech Thesis), Nirma University, May 2010.

[11]. IS 456:2000. Plain and reinforced concrete code of practice. Bureau of Indian Standards. New Delhi.

[12]. IS 1893:2002. Criteria for earthquake resistant design of structures. Bureau of Indian Standards. New Delhi.

[13]. IS 875(Part-3):1987.Code of practice for design loads (other than earthquake) for buildings and structures, Bureau of Indian Standards. New Delhi.

[14]. FEMA. 2000. Prestandard and Commentary for the Seismic Rehabilitation of Buildings, FEMA-356, Federal Emergency Management Agency, Washington, D.C.

\section{BIOGRAPHIES}

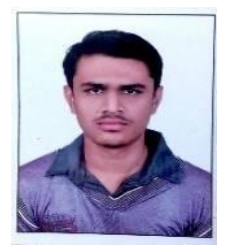

Mr. Pragnesh C. Patel has done his M. Tech in Civil Engineering with specialization in Computer Aided Structural Analysis \& Design (CASAD) from Civil Engineering Department, Institute of Technology, Nirma University

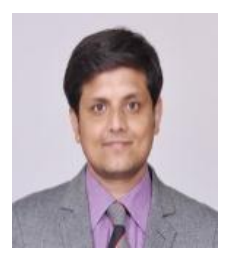

Prof. Digesh D. Joshi is working as an Assistant Professor in Civil Engineering Department of Institute of Technology, Nirma University. He is having 05 years of teaching experience.

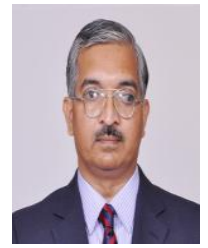

Dr. Paresh V. Patel is working as Professor \& Head of Civil Engineering Department, Institute of Technology, Nirma University. $\mathrm{He}$ is having 20 years of academic experience of teaching at UG and PG level. 